\title{
THE INCIDENCE OF OESTRUS DURING LACTATION IN FINNISH LANDRACE, DORSET HORN AND FINN-DORSET SHEEP
}

\author{
R. B. LAND \\ A.R.C. Animal Breeding Research Organisation, \\ West Mains Road, Edinburgh EH9 $37 Q$
}

(Received 22nd December 1969)

\begin{abstract}
Summary. The incidence of oestrus was observed in thirteen Finnish Landrace, twenty-five Dorset Horn and 123 Finn-Dorset females between 0 and 56 days after lambing in the spring of 1968, and in 133 Finn-Dorset females between 10 and 56 days after lambing in the spring of 1969.

In 1968, $100 \%$ of the Finnish Landrace, $68 \%$ of the Dorset Horn and $59 \%$ of the crossbred ewes showed an oestrus and of those mated, $77 \%, 29 \%$ and $40 \%$, respectively, conceived. In $1969,23 \%$ of the females showed an oestrus, of which $71 \%$ were fertile. Within the Finn-Dorsets, the mean incidence of oestrus was found to be positively correlated with the age of the females $(r=0.97)$.

In addition to the normal 17-day oestrous cycles, many of the sheep displayed oestrus around 7 days after the preceding oestrus.

The hypothesis is advanced that a high level of gonadotrophic stimulation is an important common factor underlying the various aspects of increased reproductive activity in Finnish Landrace sheep.
\end{abstract}

\section{INTRODUCTION}

The natural occurrence of oestrus during lactation can only be observed in sheep which 'lamb' before the end of their breeding season, and consequently most of the observations in the literature refer to breeds with extended breeding seasons. Within these breeds, however, the interval between lambing and the next fertile oestrus is not solely dependent upon the length of the breeding season. Crossbreeding with the Dorset Horn has been found to reduce the number of days to the next fertile oestrus in pure-bred Merino and Blackhead Persian ewes from 103 and 90 days, respectively, to 42 and 51 days in the cross-breds (Joubert, 1962). Dorper, Döhne Merino and Merino ewes, all of which have long breeding seasons, were found to have post-partum intervals varying from 69 days for the Merino to 94 days for the Döhne Merino (Van Niekirk \& Mulder, 1965). Although the heritability of this trait has not been measured within a breed, it is clear from breed and cross comparisons that variation in this trait is partially under genetic control. 
The incidence of oestrus during lactation was investigated in Finnish Landrace $\times$ Dorset Horn ewes and their parental breeds of sheep during an attempt to measure their reproductive performance and to assess their suitability for genetic studies.

\section{MATERIALS AND METHODS}

Finnish Landrace sheep were imported to Scotland in 1962, and a population of Finnish Landrace $\times$ Dorset Horn (Finn-Dorset) sheep established at the Animal Breeding Research Organisation's (ABRO) Blythbank Farm in Peeblesshire, Scotland. The farm is situated $255 \mathrm{~m}$ above sea level, at latitude $55^{\circ} 42^{\prime \prime}$ and longitude $3^{\circ} 22^{\prime \prime}$ west.

The Finn-Dorset sheep, together with some of the pure-breds, were mated from Days 208 to 257 and 236 to 271 in 1967 and 1968, respectively. The sheep were brought indoors at least 7 days before lambing, and kept indoors until after the time of weaning. Supplementary lighting had to be used on those occasions when the natural daylight was otherwise inadequate for feeding, the supervision of lambing or the detection of oestrus between 07.00 and 18.00 hours, and outside these hours for the supervision of lambing. Although the extent of this lighting varied from day to day, and neither its intensity nor that of the natural daylight was recorded, each breed type was treated in the same way. The lambs were left with their mothers until $42 \pm 3$ days of age, when they were removed for progressively increasing periods each day until they were separated for $12 \mathrm{hr} /$ day at $56 \pm 3$ days of age, when they were removed permanently.

Oestrus was detected by introducing a vasectomized ram to the females twice a day ( 09.00 and 16.00 hours), and removing those in oestrus before the ram copulated with them. The fertility of an oestrus was determined by mating with an intact ram at the time of detection, and again 9 or $17 \mathrm{hr}$ later. With some exceptions that will be noted, all ewes were tested each day for at least 56 days after lambing. The day of lambing was recorded for ewes which became pregnant during lactation, and the gestation length checked.

\section{RESULTS}

The incidence of oestrus in Finnish Landrace, Dorset Horn and Finn-Dorset females

Thirteen Finnish Landrace, twenty-five Dorset Horn and 123 Finn-Dorset females lambed in the spring of 1968, their average ages being 3.5, 4.7 and $2 \cdot 4$ years, respectively. The proportion of these females which displayed oestrus within 2 days of lambing and between 3 and 56 days after lambing are given in Table 1. In each breed type, there is a slight but non-significant decline in the proportion of individuals showing a post-partum oestrus within 2 days of lambing as the number of lambs suckled increases, but no indication of such a relationship between the incidence of oestrus later in lactation and the number of lambs ultimately weaned from the ewes.

The proportion of females which showed oestrus within 2 days of lambing $(20$ to $38 \%)$ did not differ significantly from one breed type to another $(P>0.05)$, 
but a larger proportion of the Finnish Landrace (100\%) displayed oestrus between 3 and 56 days after lambing than did the Dorset Horn $(68 \%)$ or Finn-Dorset females (59\%).

The Finn-Dorset data was also analysed within the different age groups of the females and the mean incidence of oestrus between 3 and 56 days after lambing was found to be positively correlated with the age of the female $(r=+0.97)$. The regression of the percentage of females showing oestrus on the age of female was calculated to be $0 \cdot 78 \pm 0 \cdot 12 \%$ per month of age. The use of this regression to correct the incidence of oestrus in each of the three breed types to that which would be expected if they had all been the same age ( 3 years) modified the incidence to $95 \%, 65 \%$ and $52 \%$ in the Finnish Landrace,

\section{TABLE 1}

THE NUMBER AND PERGENTAGE OF FINNISH LANDRAGE, DORSET HORN AND FINN-DORSET EWES SHOWING OESTRUS WITHIN 56 DAYS OF LAMBING

\begin{tabular}{|c|c|c|c|c|c|c|c|}
\hline \multirow{3}{*}{$\begin{array}{l}\text { Breed } \\
\text { and year }\end{array}$} & \multirow{3}{*}{$\begin{array}{l}\text { No. of } \\
\text { lambs weaned }\end{array}$} & \multirow{3}{*}{$\begin{array}{c}\text { No. of } \\
\text { ewes lambing }\end{array}$} & \multicolumn{5}{|c|}{ Period of observation } \\
\hline & & & \multicolumn{2}{|c|}{$\begin{array}{l}0 \text { to } 2 \text { days } \\
\text { after lambing }\end{array}$} & \multicolumn{3}{|c|}{$\begin{array}{l}3 \text { to } 56 \text { days } \\
\text { after lambing }\end{array}$} \\
\hline & & & No. & $\%$ & No. & $\%$ & $\begin{array}{c}\text { Mean interval (days) } \\
\pm S . E .\end{array}$ \\
\hline $\begin{array}{l}\text { Finn } \\
(1968)\end{array}$ & $\begin{array}{c}0 \\
1 \\
2 \\
3 \\
\text { All ewes }\end{array}$ & $\begin{array}{r}0 \\
3 \\
9 \\
1 \\
13\end{array}$ & $\begin{array}{l}\overline{2} \\
3 \\
0 \\
5\end{array}$ & $\begin{array}{r}\overline{67} \\
33 \\
0 \\
38\end{array}$ & $\begin{array}{r}-3 \\
9 \\
1 \\
13\end{array}$ & $\begin{array}{l}1 \overline{100} \\
100 \\
100 \\
100\end{array}$ & $\begin{array}{l}33 \cdot 3 \pm 4 \cdot 41 \\
33 \cdot 9 \pm 5 \cdot 57 \\
49 \cdot 0 \\
34 \cdot 9 \pm 4 \cdot 05\end{array}$ \\
\hline $\begin{array}{l}\text { Dorset } \\
\text { (1968) }\end{array}$ & $\begin{array}{c}0 \\
1 \\
2 \\
3 \\
\text { All ewes }\end{array}$ & $\begin{array}{r}0 \\
10 \\
15 \\
0 \\
25\end{array}$ & $\begin{array}{l}\overline{3} \\
2 \\
5\end{array}$ & $\begin{array}{l}\overline{30} \\
\frac{13}{20}\end{array}$ & $\begin{array}{r}5 \\
\frac{11}{17}\end{array}$ & $\begin{array}{l}\overline{60} \\
\overline{73} \\
68\end{array}$ & $\begin{array}{c}41 \cdot 5 \pm 6 \cdot 09 \\
42 \cdot 2 \pm 2 \cdot 73 \\
41 \cdot 9 \pm 2 \cdot 67\end{array}$ \\
\hline \multirow[t]{2}{*}{$\begin{array}{l}\text { Finn- } \\
\text { Dorset } \\
\text { (1968) }\end{array}$} & \multirow[t]{2}{*}{$\begin{array}{c}0 \\
1 \\
2 \\
3 \\
\text { All ewes }\end{array}$} & \multirow[t]{2}{*}{$\begin{array}{r}7 \\
62 \\
54 \\
0 \\
123\end{array}$} & $\begin{array}{r}3 \\
24 \\
19 \\
46\end{array}$ & $\begin{array}{l}43 \\
39 \\
39 \\
37\end{array}$ & $\begin{array}{r}4 \\
31 \\
38 \\
73\end{array}$ & $\begin{array}{l}57 \\
50 \\
70 \\
59\end{array}$ & $\begin{array}{c}37 \cdot 2 \pm 5 \cdot 75 \\
27 \cdot 6 \pm 2 \cdot 62 \\
31 \cdot 6 \pm 1 \cdot 90 \\
30 \cdot 2 \pm 1.53\end{array}$ \\
\hline & & & & & \multicolumn{3}{|c|}{10 to 56 days } \\
\hline $\begin{array}{l}\text { Finn- } \\
\text { Dorset } \\
\text { (1969) }\end{array}$ & $\begin{array}{c}0 \\
1 \\
2 \\
3 \\
\text { All ewes }\end{array}$ & $\begin{array}{r}2 \\
35 \\
87 \\
10 \\
133\end{array}$ & $\begin{array}{l}= \\
= \\
=\end{array}$ & $\begin{array}{l}E \\
z \\
-\end{array}$ & $\begin{array}{r}0 \\
6 \\
23 \\
2 \\
31\end{array}$ & $\begin{array}{r}0 \\
17 \\
26 \\
20 \\
23\end{array}$ & $\begin{array}{c}38 \cdot 3 \pm 3 \cdot 56 \\
42 \cdot 5 \pm 1 \cdot 72 \\
38 \cdot 0 \pm 7 \cdot 00 \\
41 \cdot 4 \pm 1 \cdot 50\end{array}$ \\
\hline
\end{tabular}

Finn-Dorset and Dorset Horn females, respectively. This correction did not change the initial conclusion that the incidence was significantly higher in the Finnish Landrace than the other breed types, but did indicate that the incidence in the Finn-Dorsets was within, rather than outside, the range of the parental types.

In the spring of 1969, 133 Finn-Dorset females between 2 and 6 years old lambed. The occurrence of oestrus was observed in these females from 10 to 56 days after lambing, and the incidence is given in Table 1. Despite the greater 
age of this group of females and the fact that the regression of incidence on age was similar in the 2 years, the incidence of oestrus was significantly lower $(P<0.01)$ than in 1968 ( 23 versus $59 \%)$.

The fertility of the oestrous periods displayed during lactation was checked in all Finnish Landrace and Dorset Horn females and in twenty of the Finn-Dorset females in 1968. In 1969, all Finn-Dorsets were mated with a fertile ram at each oestrus displayed between 10 and 56 days after lambing. The proportion of these females which became pregnant is given in Table 2. A significantly

TABLE 2

THE NUMBER OF FINNISH LANDRACE, DORSET HORN AND FINN-DORSET EWES WHICH BECAME PREGNANT FOLLOWING MATING WITHIN 56 DAYS OF LAMBING, TOGETHER WITH THE MEAN INTERVAL BETWEEN LAMBING AND THAT MATING

\begin{tabular}{|c|c|c|c|c|c|}
\hline \multirow[b]{2}{*}{$\begin{array}{c}\text { Breed } \\
\text { and year }\end{array}$} & \multirow[b]{2}{*}{$\begin{array}{c}\text { No. of } \\
\text { lambs weaned }\end{array}$} & \multicolumn{3}{|c|}{ Ewes } & \multirow[b]{2}{*}{$\begin{array}{l}\text { Mean interval } \\
\pm S . E . \text { (days) }\end{array}$} \\
\hline & & $\begin{array}{c}\text { No. } \\
\text { mated }\end{array}$ & $\underset{\text { pregnant }}{\text { No. }}$ & $\begin{array}{c}\% \\
\text { pregnant }\end{array}$ & \\
\hline $\begin{array}{l}\text { Finn } \\
(1968)\end{array}$ & $\begin{array}{c}0 \\
1 \\
2 \\
3 \\
\text { All ewes }\end{array}$ & $\begin{array}{r}0 \\
3 \\
9 \\
1 \\
13\end{array}$ & $\begin{array}{r}-1 \\
9 \\
0 \\
10\end{array}$ & $\begin{array}{r}\overline{33} \\
100 \\
0 \\
77\end{array}$ & $\begin{array}{l}43.0 \\
41 \cdot 2 \pm 2.84 \\
41 \cdot 4 \pm 2.54\end{array}$ \\
\hline $\begin{array}{l}\text { Dorset } \\
\text { (1968) }\end{array}$ & $\begin{array}{c}0 \\
1 \\
2 \\
3 \\
\text { All ewes }\end{array}$ & $\begin{array}{r}0 \\
6 \\
11 \\
0 \\
17\end{array}$ & $\begin{array}{l}\overline{2} \\
\frac{3}{5}\end{array}$ & $\begin{array}{l}\overline{33} \\
27 \\
29\end{array}$ & $\begin{array}{c}47 \cdot 5 \pm 6 \cdot 50 \\
52 \cdot 7 \pm 2 \cdot 41 \\
50 \cdot 6 \pm 2 \cdot 75\end{array}$ \\
\hline $\begin{array}{l}\text { Finn- } \\
\text { Dorset } \\
\text { (1968) }\end{array}$ & $\begin{array}{c}0 \\
1 \\
2 \\
3 \\
\text { All ewes }\end{array}$ & $\begin{array}{r}1 \\
8 \\
11 \\
0 \\
20\end{array}$ & $\begin{array}{l}0 \\
1 \\
7 \\
8\end{array}$ & $\begin{array}{r}0 \\
13 \\
64 \\
40\end{array}$ & $\begin{array}{l}42 \cdot 0 \\
46 \cdot 4 \pm 1.93 \\
45.9 \pm 1.76\end{array}$ \\
\hline $\begin{array}{l}\text { Finn- } \\
\text { Dorset } \\
\text { (1969) }\end{array}$ & $\begin{array}{c}0 \\
1 \\
2 \\
3 \\
\text { All ewes }\end{array}$ & $\begin{array}{r}0 \\
6 \\
23 \\
2 \\
31\end{array}$ & $\begin{array}{r}- \\
3 \\
18 \\
1 \\
22\end{array}$ & $\begin{array}{l}-\overline{50} \\
78 \\
50 \\
71\end{array}$ & $\begin{array}{l}43.0 \pm 1.73 \\
44.6 \pm 1.05 \\
48 \cdot 0 \\
44.5 \pm 0.90\end{array}$ \\
\hline
\end{tabular}

greater proportion $(P<0.05)$ of the mated Finnish Landrace females $(77 \%)$ became pregnant in 1968 than the Dorset Horns (29\%) or Finn-Dorsets (40\%). The proportion of females lambing to a mating during lactation was greater in 1969 than 1968, 71 and $40 \%$ of mated Finn-Dorsets becoming pregnant in the 2 years, respectively. The number of females which showed a fertile oestrus during lactation was, however, a similar proportion of the number lambing in both years-17\% in 1969 compared to an expectation of $24 \%$ in 1968 .

None of the ewes became pregnant to a mating within 2 days of lambing. The main interval to first oestrus (excluding post-partum oestrus) and first fertile oestrus for the three groups of sheep in 1968 and the cross-breds in 1969 is given in Tables 1 and 2. The effects of age of ewe, number of lambs born, number of lambs weaned, day of lambing and year of observation on the interval to first oestrus of cross-bred ewes were tested by a multiple regression 
analysis. Of these variables, the only one to have a large or statistically significant $(P<0.05)$ effect was the year of observation, the mean interval to first oestrus being 10 days longer in 1969 than in 1968.

The intervals between successive oestrous periods during lactation

The distribution of the interval between lambing and first oestrus in each of the three breed types in 1968 is illustrated in Text-fig. 1, from which it can be

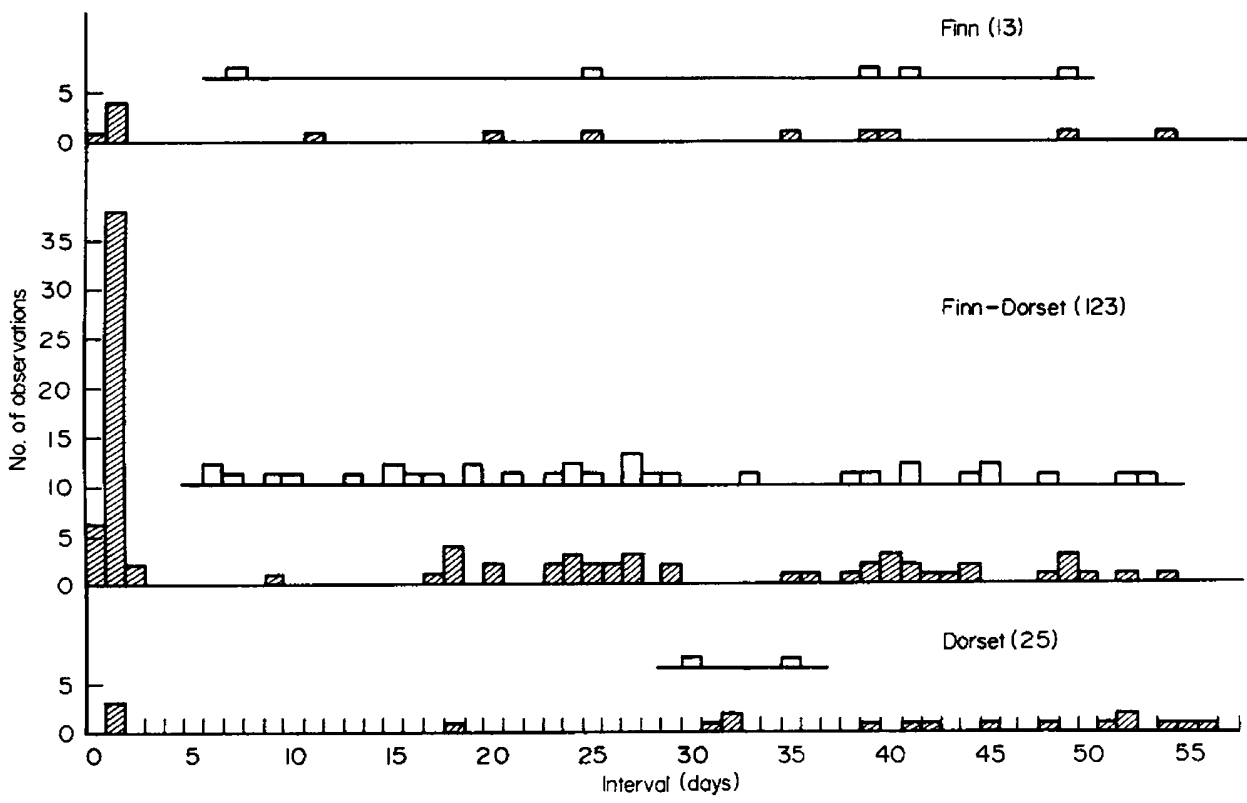

TEXT-FIG. 1. The distribution of the interval (in days) between lambing and first oestrus (hatched symbols) in Finnish Landrace, Dorset Horn and Finn-Dorset females in 1968, together with the distribution of the interval between an oestrus displayed within 2 days of lambing and the next oestrus displayed during lactation (open symbols). The total number of ewes of each breed type is given in parentheses.

seen that the modal interval in each group of sheep is one day. The distribution of the intervals between lambing and the first non-post-partum oestrus is, however, largely independent of the occurrence of oestrus within 2 days of lambing: the intervals between a post-partum oestrus and the next oestrus between 3 and 56 days after lambing (Text-fig. 1, open symbols) having the same distribution as the intervals between lambing and the first oestrus of ewes which did not show a post-partum oestrus (Text-fig. 1, hatched symbols, Days 3 to 56). Both distributions, however, contrast strongly with the distribution of intervals observed between 3 and 56 days after lambing (Text-fig. 2).

The distribution of intervals between oestrous periods displayed by ewes which returned to oestrus between 3 to 56 days after lambing (Text-fig. 2) appears to be basically bimodal in all three breed types, the ewes returning to oestrus at intervals of approximately 7 or 17 days. Of a total of ninety intervals represented, twenty-nine are of approximately 7 days, and forty-eight of approximately 17 days. A large proportion of the oestrous cycles which occurred 
during lactation have therefore been shortened from 17 to 7 days. In 1969, however, only five ewes showed two successive heats between 10 and 56 days after lambing. Each ewe showed heats approximately 17 days apart.

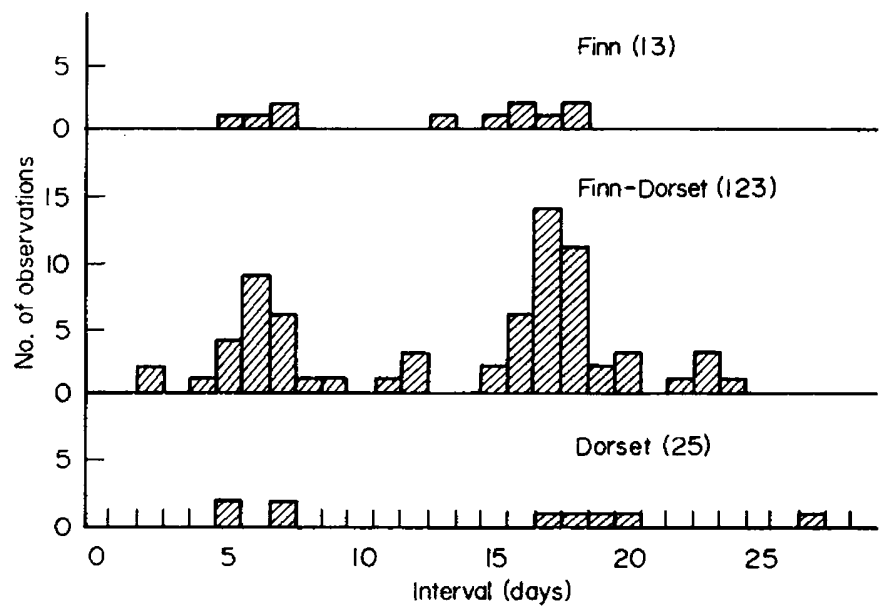

Text-Fig. 2. The distribution of the intervals between successive oestrous periods displayed by Finnish Landrace, Dorset Horn and Finn-Dorset females which returned to oestrus between 3 and 56 days after mating in 1968. The total number of ewes of each breed type is given in parentheses.

\section{DISCUSSION}

The relatively high proportion of Finnish Landrace ewes showing heat and becoming pregnant during lactation indicates that the Finnish sheep can not only make a contribution to the litter size of British breeds of sheep, but also to their fertility after lambing. This conclusion is supported by the fact that the Finnish Landrace ewes were superior in this respect to the Dorset ewes and that Dorset crosses themselves have been found to be superior to Merino and Persian ewes (Joubert, 1962). The difference between the performance of the Finn-Dorset crosses in 1968 and 1969, however, indicates that environmental factors play a large part in the control of this trait. Which particular component of the environment is responsible for this variation cannot be determined from the present data, but in spite of efforts to control the feeding of the animals, it is possible that nutritional differences which Hunter (1968) concluded were of considerable importance, could be responsible. Differences in the supplementation of daylight could also have contributed to the betweenyear effects, but the failure of Ducker, Thwaites \& Bowman (1970) to detect changes in the duration of the cyclical activity of Teeswater-Clun ewes given various supplemented day lengths indicates that this factor may not have had a large effect.

In addition to the effects of nutrition, Hunter (1968) reviews the effects of age, number born, number weaned and the day of lambing on the interval between lambing and the next oestrus, but is unable to reach any general conclusions. Of these variables, the only one found to be important in the Finn- 
Dorset population was the age of the ewe, which, although unrelated to the interval between lambing and first oestrus in those ewes which showed heat between Days 3 or 10 and Day 56 of lactation, was positively correlated with the proportion of individuals which showed an oestrus during this time. It is possible to conclude from this aspect of the study that some Finn-Dorset females show oestrus during lactation, and that genetic variation in the incidence may be present in the crossbred population. The results indicate, therefore, that this population would be suitable for a study of the genetic control of the display and fertility of oestrus during lactation.

The total infertility of matings which took place within 2 days of lambing was also observed by Barker \& Wiggins (1964) who concluded from an examination of the ovaries of some of the ewes concerned that follicular development and ovulation had not taken place. Similarly, the reduced fertility of oestrous periods displayed later in lactation is in accordance with the increase in fertility as the interval between lambing and mating of Karakul sheep increased (Nel, 1965). However, in addition to the suppression both of the display of oestrus and the fertility of oestrus following lambing, an examination of the incidence of oestrous periods during lactation shows that a large proportion of the intervals between successive oestrous periods were only 7 days in length. This reduction of the di-oestrous interval may indicate that oestrus during lactation is not always followed by the formation of normal corpora lutea and hence that some aspect of the process of luteinization is disturbed, a conclusion which is also compatible with the lowered fertility of oestrous periods which are followed by apparently normal 17-day oestrous cycles. The present data are not sufficient to determine which of the factors controlling the establishment of normal luteal activity are responsible for the failure of the formation or maintenance of normal corpora lutea. The observations that treatment with luteinizing hormone (LH) or with human chorionic gonadotrophin but not with prolactin, alleviated oxytocin-induced inhibition of the second of two essential luteotrophic stimuli in the cow (Donaldson, Hansel \& Van Vleck, 1965), and that LH synthesis is suppressed in the sow during lactation (Crighton \& Lamming, 1969), however, suggest that luteal deficiency may be the result of inadequate release of LH. If so, the relatively high proportion of Finnish Landrace ewes displaying oestrus and becoming pregnant during lactation suggests that they are able to overcome this post-gestational suppression of $\mathbf{L H}$ stimulation more easily than the Dorsets.

The reproductive activity of Finnish Landrace ewes during lactation complements earlier observations that these ewes have larger litters than other breeds of sheep (Maijala, 1966; Donald \& Read, 1967), that their cross-bred young have a greater proportion of oocytes with antra at birth (Land, 1970a), that their oestrous periods are of a longer duration (Land, 1970b) and that the males have a higher libido (Land, 1970c), and gives some indication of the nature of the physiological variation underlying this increased performance. Since both sexes are involved, the high reproductive activity of the Finnish Landrace sheep is probably due to a factor common to both, and is therefore more likely to be due to greater gonadotrophic activity than to increased gonadal sensitivity. The observation of high gonadal activity in each of the 
physiological states studied implies that high gonadotrophic activity is a general attribute of the breed. These indications suggest that it may be possible to base genetic selection for improving the reproductive performance of sheep on the level of gonadotrophic activity of young animals of both sexes.

\section{ACKNOWLEDGMENTS}

I wish to thank Mr T. H. McGlelland and Mr J. C. Harris for the supervision of sheep, Mr E. Hughes and the Blythbank staff for collecting the data, Mrs H. F. Kelley for computing assistance, and Mr W. S. Russell for the use of his programme for multiple regression analysis.

\section{REFERENCES}

BARKer, H. B. \& Wiggins, E. L. (1964) Occurrence of post-partum estrus in fall-lambing ewes. 7. Anim. Sci. 23, 967.

Crighton, D. B. \& Lamming, G. E. (1969) The lactational anoestrus of the sow: the status of the anterior pituitary-ovarian system during lactation and after weaning. F. Endocr. 40, 507.

Donald, H. P. \& Read, J. L. (1967) The performance of Finnish Landrace sheep in Britain. Anim. Prod. 9, 471.

Donaldson, L. H., Hansel, W. \& VAN Vleck, L. D. (1965) Luteotrophic properties of luteinizing hormone and nature of oxytoxin induced luteal inhibition in cattle. F. Dairy Sci. 48, 331.

Ducker, M. J., Thwaites, C. J. \& Bowman, J. C. (1970) Photoperiodism in the ewe. 1. The effect of long supplemented daylengths on the breeding activity of pregnant and non-pregnant Teeswater-Glun ewes. Anim. Prod. 12, 107.

Hunter, G. L. (1968). Increasing the frequency of pregnancy in sheep. Anim. Breed. Abstr. 36, 347.

Joubert, D. M. (1962) Sex behaviour in purebred and crossbred Merino and Blackhead Persian ewes. 7. Reprod. Fert. 3, 41.

LAND, R. B. (1970a) The number of oocytes present at birth in the ovaries of pure and Finnish Landrace cross Blackface and Welsh sheep. 7. Reprod. Fert. 21, 517.

LAND, R. B. (1970b) A relationship between the duration of oestrus, ovulation rate and litter size of sheep. F. Reprod. Fert. 23, 49.

LAND, R. B. (1970c) The mating behaviour and semen characteristics of Finnish Landrace and Scottish Blackface rams throughout the year. Anim. Prod. (in press).

Maijala, K. (1966) Causes of variation in litter size of Finn-sheep ewes. 9th Int. Congr. Anim. Prod. Edinburgh, Abstracts, p. 29.

Nel, J. A. (1965) Post partum sex activity in Karakul sheep. Proc. S. Afr. Soc. Anim. Prod. 4, 200.

VAN NIEKERK, B. D. H. \& MULDER, A. M. (1965) Duration of pregnancy and of post partum anoestrus in autumn-mated Dorper, Döhne Merino and Merino ewes. Proc. S. Afr. Soc. Anim. Prod. 4, 205. 